\title{
Kumani-Kipčaci između Azije i Europe u razvijenome i kasnome srednjem vijeku
}

DOI: $10.11567 /$ met.31.2.3

UDK: 94(4/5)"10/12"(=512.144)

Pregledni rad

Primljeno: 14 .04. 2015.

Prihvaćeno: 21. 09. 2015.

\section{Mirko Sardelić}

Odsjek za povijesne znanosti HAZU, Zagreb

msardelic@hazu.hr

\section{SAŽETAK}

Cilj je ovoga rada da bude polazišna točka za poznavanje i daljnje istraživanje Kumana, jedne od turkijskih etničkih skupina euroazijske stepe. Ta nomadska konfederacija nikad nije utemeljila državnu zajednicu, ali je plaćenička kumanska konjica redovito donosila prevagu u sukobima među ruskim kneževinama, u bugarsko-bizantskim ratovima, u sukobima među pretendentima na prijestolje u Ugarskoj i Srbiji te drugdje. Najviše će biti riječi o vrhuncu njihova utjecaja (1050. - 1240.), kada su kontrolirali područje od Aralskoga jezera do donjega dunavskog bazena. Gordlevski je smatrao da je proučavanje turkijskih naroda usko povezano s proučavanjem Mongola, koji su mnoge turkijske narode euroazijske stepe inkorporirali u svoje nepregledno carstvo. Jednako se tako ni srednjovjekovna povijest jugoistočne Europe ne može proučavati bez povijesti turkijskih naroda. Kumani su bili poznati po tome da su rado odvodili ljude u ropstvo, no naposljetku su i sami bili najbrojniji robovi koji su se u crnomorskoj regiji prodavali u Italiju te na Bliski i Srednji istok. Upravo je kumanski jezik ostao lingua franca u području euroazijske stepe, gdje ga i danas razumije većina turkijskih naroda. U (jugo)istočnoj Europi Kumani su se polako stopili $\mathrm{u}$ šareni etnički amalgam stanovništva slavenskoga, ugrofinskog i turkijskog podrijetla. U Aziji su pridonijeli stvaranju Kazaka, Uzbeka, Kirgiza i drugih turkijskih naroda. Baština Kumana upletena je u desetke europskih i azijskih nacija te je zbog toga proučavanje kumanske povijesti važno kao platforma za razumijevanje šireg okvira euroazijskih migracija te odnosâ među nomadskim i sjedilačkim društvima na tom prostoru.

KLJUČNE RIJEČI: Kumani-Kipčaci, euroazijska stepa, turkijski narodi, euroazijski nomadi, srednji vijek, Jugoistočna Europa 


\section{UVOD:PODRUČJE DODIRA EUROPE I AZIJE}

Trinaesto je stoljeće doba europske »renesanse prije renesanse« te početno razdoblje europskoga širenja, ponajprije na Istok. ${ }^{1}$ Preduvjeti su već bili stvoreni: u križarskim su pohodima ostvareni dodiri s bliskoistočnim narodima, a novoosnovani redovi franjevaca i dominikanaca proširili su granice kršćanskoga svijeta sjeverom i istokom kontinenta. No onda je zapravo, kao i prethodnih stoljeća s Hunima, Avarima i Mađarima, Azija s Mongolima došla i otvorila se Europi, koja je sada bila spremna otkriti i demistificirati novi svijet. Da bi se bolje razumjela povijest jugoistočne Europe, treba je promatrati i iz azijske perspektive. ${ }^{2}$ Naime koliko god su u njezinim temeljima kršćanska i europska tradicija, njezino je formativno razdoblje vezano uz azijske nomade, upravo zbog njezina smještaja na području tih dodira. Parafrazirajući riječi V. Gordlevskoga - »Da bi se razumjela povijest turkijskih naroda, važno je proučavati Mongole« - da bi se razumjela povijest istoka Europe, neophodno je poznavati i povijest Kumana te Mongolskoga Carstva. ${ }^{3}$ Ovaj je članak obol poznavanju upravo te sastavnice povijesti Europe, ali ponajprije hommage kumanskoj svjetskoj baštini. Cilj je rada analizirati ulogu Kumana-Kipčaka i povezati je s nastankom srednjovjekovnih država na trima kontinentima: Europi, Aziji i Africi.

Pojavljivanje azijskih nomada u istočnoj i srednjoj Europi redovito je bilo posljedica etničkih »tektonskih « pomicanja u središnjoj Aziji. Tako je i provala Mađara i Pečenega (9. stoljeće) vezana uz pritisak jakoga Kimečkog Kaganata, koji je bio dominantna turkijska konfederacija na području između rijeke Irteš na istoku i Kaspijskoga jezera na zapadu između sredine 8. i sredine 11. stoljeća (Плетнева, 2010: 31-42). To je prvi vremenski okvir Kipčaka-Kumana, koji ovdje samo spominjemo. U Kimečkom Kaganatu na-

1 Rad je nastao u sklopu autorova projekta »The role of emotions in contacts between Eurasian cultures", stipendiranog programom NEWFELPRO u ARC Centre of Excellence for the History of Emotions: Europe 1100-1800 na University of Western Australia (UWA).

2 U hrvatskoj je historiografiji vrijedan recentniji prilog o toj temi članak autora E. Heršaka i S. Lazanin (1999). Emil Heršak autor je još nekoliko važnih priloga o euroazijskim migracijama, primjerice o etnogenezi i povijesti Avara (Heršak i Silić, 2002) te o migracijama uralskih naroda (Heršak, 2001).

3 Jedna od najvažnijih knjiga za poznavanje povijesti Mongolskoga Carstva i odnosa Europe s Azijom u 13. i 14. stoljeću je The Mongols and the West, 1221-1410 (Jackson, 2005). Za pregled povijesti turkijskih naroda unutar povijesti mongolskoga svijeta $\mathrm{u}$ istom razdoblju vidi: Kadyrbaev (2005) koji i počinje navedenim citatom. Sada su već podosta stari pregledi povijesti Kumana, koje su sastavili Голубовский (1884) і Расовский (1935-1940), a riječ je o vrlo korisnim djelima popraćenima brojnim bilješkama, u kojima se može naći i većina starije literature; recentnija su pregledna izdanja povijesti Kumana: Пилипчук, 2013 te Иванов, Гарустович і Пилипчук, 2014. 
laze se i plemena Kipčaka, koji u 9. i 10. stoljeću žive oko rijeka Tobol i Išim u jugozapadnom Sibiru. Slabljenjem Kimeka glavnu ulogu na tom području preuzimaju Kipčaci, dotad podređeni u velikoj konfederaciji, i njihovi se kanovi nalaze uglavnom u području Syr-Daryje i Urala (Klyashtornyj, 2005: 243; Golden, 1998: 185; Ахинжанов, 1995: 154-180). Doduše, prilikom rasformiranja Kimečkoga Kaganata i selidbe na zapad nastale su tri veće kipčačke skupine: prva je ušla u južnoruske stepe oko rijeke Volge, u drugoj su oni u području Syr Darye, dok su u trećoj ostali izdvojeni sibirski Kipčaci, koji će poslije ući u sastav sibirskih Tatara (Golden, 1990: 278-279).

Najviše će biti riječi o tome drugom vremenskom okviru (1050. - 1240.), zbog toga što se on najviše tiče Europe: sredinom 11. stoljeća dolazi do migracije u kojoj dio kipčačke federacije dolazi do crnomorske stepe (Vásáry, 2005a: 116; Ахинжанов, 1995: 181-184), južno od ruskih kneževina. Treći je vremenski okvir onaj u kojemu su do sredine 13. stoljeća najveći dio euroazijske stepe osvojili Mongoli. Mongolsko Carstvo na cijelu zapadnu stepu dovodi nove mongolske i napose turkijske narode, povećavajući već prilično složeni etnički amalgam. Već sredinom 13. stoljeća Mongolsko se Carstvo razdijelilo na četiri (još uvijek goleme) sastavnice: zemlje velikoga kana na istoku, Čagadajev Kanat, Perzijski Kanat (Ilkanat) te Zlatnu Hordu. Ova je posljednja nadživjela sve ostale, a nazivala se još i Kipčačkim Kanatom, zbog toga što se velikim dijelom preklapala s prostorom pod kumanskim utjecajem (slika 1). Osim vremenskih okvira u radu će biti promatrana i tri geografska - europski, azijski i sjevernoafrički okvir kumanske prisutnosti. Dakako, ovaj pregled koji može poslužiti kao skica nekoj studiji raširenosti kumanskih utjecaja nije mogao uzeti u obzir sve njihove aspekte, pa je daleko jači naglasak stavljen na prostor jugoistočne Europe. ${ }^{4}$ Nakon općenitoga dijela o geografiji, vjerovanjima i načinu života ukratko su prikazani najznačajniji događaji iz povijesti Ugarsko-Hrvatskoga Kraljevstva, Bugarskoga Carstva i ruskih kneževina vezani uz Kumane. Bizantsko-kumanski odnosi neopravdano, između ostaloga i zbog iscrpnosti, nisu obrađeni zasebno, nego su neke crtice upletene u ostala poglavlja. ${ }^{5}$

U ovom pokušaju sagledavanja široke slike autoru su literaturom i savjetima pomogli doajen kumanologije Peter Golden te uvaženi kolege Jaroslav Pilipčuk, Aleksandar Uzelac i Nenad Vidaković. Dakako, za sve propuste i moguće netočnosti odgovornost je isključivo autorova.

5 O tome u djelima: Stephenson, 2006, Vásáry, 2004, Пилипчук, 2012, i ondje navedenim izvorima i literaturi; jednako je tako i s odnosima rumunjskih zemalja s Kumanima, o čemu više u: Spinei, 2009, Diaconu, 1978. 
Slika 1. Zlatna horda i kumanska stepa sredinom 13. stoljeća

Picture 1. Golden Horde and the Cuman steppe in the mid- $13^{\text {th }}$ century

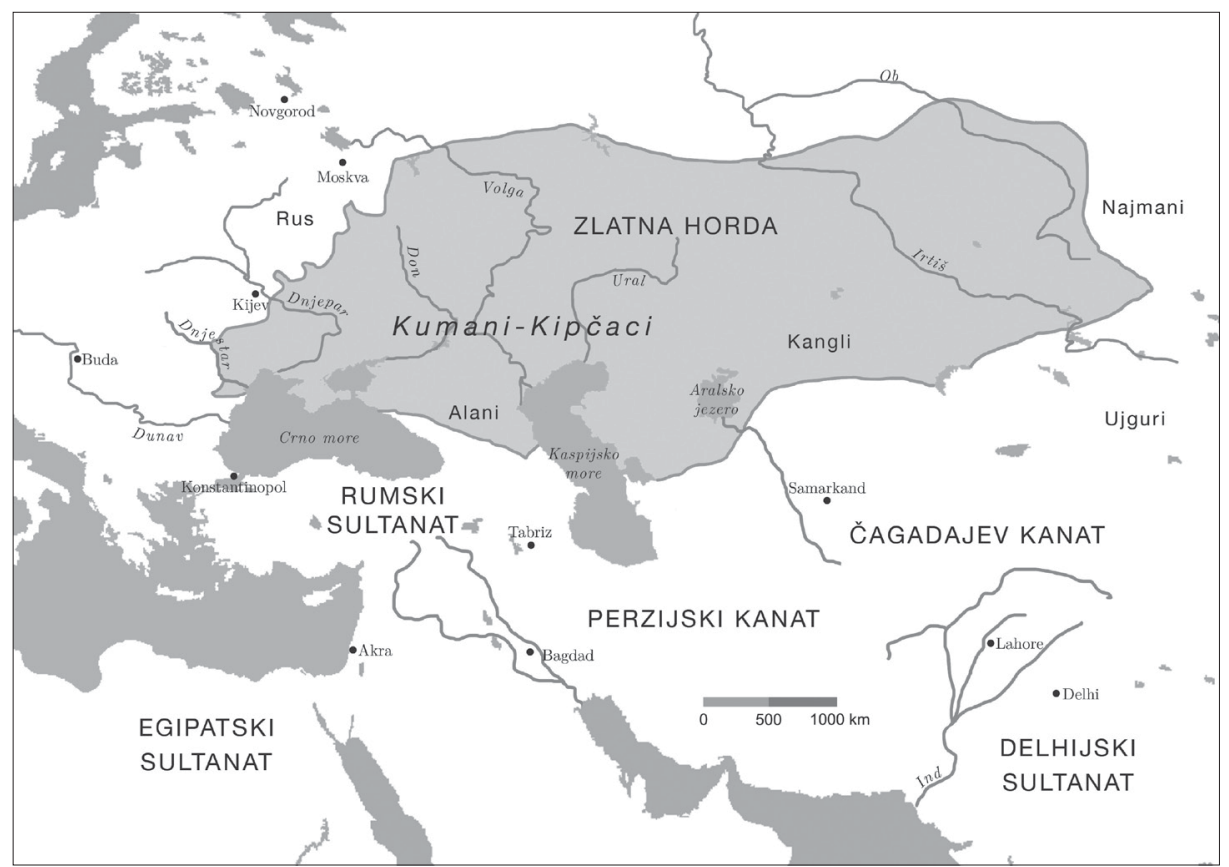

Prema autorovim uputstvima kartu izradila Dalina Dominguez.

\section{GEOGRAFSKE I ETNOGRAFSKE ODREDNICE KUMANSKOGA SVIJETA}

Što se europskog istoka tiče, između 10. i početka 13. stoljeća dvije su konfederacije nomadskih plemena vladale crnomorskom stepom, u 10. i prvoj polovini 11. stoljeća Pečenezi, a nakon njih, sve do mongolskih osvajanja, Kumani. Za razliku od Zapadnih Turaka i Hazara, koji su imali organizirane državne zajednice i kagane, i jedni i drugi bili su podijeljeni u više plemenskih jedinica. Godine 1091. zajedničke snage bizantske i kumanske vojske kod Levuniona nanose Pečenezima težak poraz (Spinei, 2009: 120), ${ }^{6}$ nakon kojega se oni polako prestaju u izvorima pojavljivati kao zasebna etnička grupa i stapaju se s drugim većim turkijskim etnicima.

$6 \quad$ Riječ je o velikoj pobjedi cara Aleksija I. Komnena kojom se Bizantsko Carstvo ponovo osovilo na noge (Stephenson, 2006: 103); obično se Bitka kod Beroje/Verije 1122. smatra posljednjom manifestacijom Pečenega i njihove borbe protiv Bizanta (Stephenson, 2006). 
Kumani su bili konfederacija turkijskih plemena, koju su njihovi mnogobrojni susjedi nazivali mnoštvom imena, između ostaloga i zbog kompozitne prirode njihove konfederacije (Golden, 2005: 248). Čak su i sami njezini pripadnici upotrebljavali različita imena. O njihovu podrijetlu napisane su mnoge rasprave (v. Golden, 1995/1996: 100-101), a Kljaštorni ih je u nekoliko naslova identificirao $\mathrm{s}$ onima koji se $\mathrm{u}$ turkijskim natpisima nazivaju Sir (Кляшторный і Савинов, 2005). Perzijanac Marvazī (oko 1120.) piše da su bili nestorijanci te da su izvorno Kumani i Kipčaci bili dva plemena. ${ }^{7}$ Bizantski izvori bilježili su ih kao Koumanoi ili Komanoi, a Rusi su ih nazivali Polovcima (»plavima« u smislu »svijetlima«), iz čega se izvode i poljska i češka varijanta, Plauci/Plawci, odnosno Plavci. ${ }^{8}$ Iz toga proizlaze i latinski oblici Pallidi, Flavi, kao i germanski Valwen, Falwen, odnosno Falones i Valani. Turkijski narodi upotrebljavali su naziv Qïpčaq, odnosno Qibčaq, s raznim varijacijama tipa qbjâk, qfjâk (Golden, 2005: 249) ili Kuman, Kinezi K'in-ča ili K'o-fu-ča, K'o-pi-čao, Mongoli Kibčag ili Kimčag, Ugri pak Kún (ili, pod utjecajem ruskoga, Palóczi), dok su u latinskim varijantama $\mathrm{C}(\mathrm{h})$ omani, Cumani (čak i Phalagi i Falones). ${ }^{9}$

Kao i ostali stepski turkijski nomadi, osim Karakanida i Seldžuka, koji su je preuzeli od sjedilačkih naroda koje su osvojili, Kumani nisu imali državu. To je bilo stoga što je euroazijska stepa pružala idealne uvjete za njihov pastoralni način života koji su dopunjavali dobrima koja su stjecali razmjenom ili pljačkom te novcem dobivenim za službu u vojskama različitih vladara (Golden, 1991, 1995/1996: 100). Osim tih »fizioloških« razloga navode se i oni politički, a vezani su uz njihove sjedilačke susjede. U prvom se redu to odnosi na ruske kneževine, od kojih se nijedna nije mogla nametnuti ostalima baš zbog prisutnosti velikog broja kumanskih klanova koji su bili spremni ratovati na strani bilo koje od njih. S druge strane, kumansko je upletanje u ruske borbe samo pojačavalo centrifugalna nastojanja već karakteristična za nomadska društva (Golden, 1979/1980: 296). Osim toga ni na globalnom planu nije bilo nikakve prijetnje koja bi bila povodom za stvaranje jače centralizirane vlasti. Čak ni na vrhuncu snage Bizant nije rado slao vojsku preko Dunava u stepu, nego se radije priklanjao potkupljivanju i međusobnom zavađanju kumanskih plemena, jednako kako su i Kinezi postupali sa svojim sjevernim barbarima (Golden, 1995/1996: 106).

Kao što su to npr. bili Mongoli i Tatari, samo što ih (udaljena) Europa nije razlikovala.

8 Diskusiju o etnonimima vidi u: Добродомов, 1978.

9 O tome Spinei, 2006: 321. Na str. 322-324 Spinei nastavlja o etimologiji imena. Valja obratiti pozornost i na to da se u izvorima 12. i 13. stoljeća Kumani spominju i kao Huni i Skiti (Spinei, 2006: 324; Golden, 1995/1996: 101; Vásáry, 2005b: 5-6; Pritsak, 1982: 323-335 detaljnije analizira različita imena; Golden, 2014). 
Na svome vrhuncu Kumani su kontrolirali područje od (danas gotovo presušenog) Aralskog jezera u današnjem Uzbekistanu do donjega dunavskog bazena. U vrijeme Mongolskoga Carstva najveći broj njih obitavao je u stepi sjeverno od Crnoga mora. Sredinom 13. stoljeća flamanski franjevac i misionar Vilim iz Rubrucka spominje da naseljavaju područje od Dunava do Tanaisa, na ušću Dona u Azovsko more, dok su prije tatarskih osvajanja živjeli i između Dona i Volge (Rubruck, 1990)..$^{10}$ Kumanska stepa okvirno se dijeli na pet plemenskih ili supraplemenskih zona: centralnoazijsku-kazahstansku, porječje Volge-Urala, donsko područje, dnjeparsko i dunavsko područje (Golden, 1990: 280; Korobeinikov, 2008: 381). Nije bilo centralne vlasti, nego su različiti kumanski kanovi djelovali neovisno, uplećući se u prilike susjednih ruskih, bizantskih ili horezmijskih zemalja. Područje naseljeno Kumanima susjedni su muslimanski izvori nazivali Dašt-i Qipčak, Rusi Zemlja Poloveckaja, a latinski izvori Cumania, i svakako treba imati u vidu da se ovaj posljednji naziv odnosio na dio kumanskoga područja najbliži nazivateljima. ${ }^{11}$

Peter Golden (1995/1996: 108-122) sabrao je iz ruskih, arapskih i perzijskih izvora nekoliko desetaka imena kumanskih klanova i plemena. Otegotna je okolnost za precizno identificiranje ta što je kumansko-kipčačka zajednica osim turkijskih plemena sadržavala mnoge druge heterogene elemente. To se u prvom redu odnosi na poturčene mongolske ${ }^{12}$ i iranske etničke skupine, što se često događalo u stepi (Golden, 1995/1996: 104). Sve to govori u prilog neopisivoj slojevitosti etničkoga sastava, kojoj uvijek treba pristupiti oprezno. Iz perspektive ruskih kneževina, napose Kijevske, Kumani su bili podijeljeni na dvije potkonfederacije: jedni su bili Divlji ili, kako su ih ruski izvori nazivali, Polovci Dikii, a drugi su bili »Ne-divlji« «, podijeljeni u dvije skupine koje su živjele u srednjem i donjem toku Dnjepra. Divlji su obitavali istočnije od Ne-divljih, a ime su dobili po tome što kijevski knezovi s njima nisu uspijevali uspostaviti dobre odnose, iako su ovi znali ulaziti i u dugotrajnija savezništva s ostalim ruskim frakcijama (Golden, 1979/1980: 296-298; Плетнева, 2010: 99-105; Pritsak, 1982: 374-377). ${ }^{14}$

10 U svome izvještaju Rubruck ih naziva Comani, dok na jednome mjestu spominje i naziv Capchac (vidi: Rubruck, 1990: 70, 99, 105-106, 108, 113, 128).

11 O Kumaniji kao imenu za Moldaviju i istočnu Vlašku u 13. stoljeću vidi u: Lăzărescu-Zobian, 1984.

12 Tome u prilog govori etimologija nekih kumanskih riječi koje antedatiraju mongolska osvajanja iz 13. stoljeća, a, dakako, i imena nekih plemena u savezu. Vidi: Golden, 1995/1996: 105, і Кръстев, 2003.

13 Taj naziv, dakako, valja shvatiti samo kao tehnički termin za razlikovanje od Divljih.

$14 \mathrm{O}$ tome više u nastavku, u dijelu rada o Kumanima i ruskim kneževinama. 
U Ipatijevskoj kronici pod godinom 1193. spominju se Lukomorski Polovci i Burčeviči, obje skupine koje spadaju u Ne-divlje. ${ }^{15}$ Postojala je još i podjela na Crne i Bijele Kumane, odnosno na Crnu i Bijelu Kumaniju (Spinei, 2008: 106-107).

\section{VJEROVANJA KUMANA}

Da bi se razumjela vjerovanja Kumana, potrebno je dati malo širi uvod. ${ }^{16}$ Kao i drugi euroazijski nomadski narodi oni štuju kult boga neba Tengrija, koji je donekle bliži konceptu monoteističkih religija mediteranskoga kruga. Tengri je najvažnija figura staroturkijskog panteona, bog koji je među stvorenim stvarima zaveo red (Golden, 1998: 211). No njegovo štovanje samo je dijelom kompleksnoga sustava vjerovanja koji se naziva šamanističkim. ${ }^{17}$ Srednjovjekovne kronike spominju da štuju nebeska tijela i, kao i ostali turkijski narodi, vatru (Spinei, 2006: 350). Da bi sve dobilo i dodatne komponente, valja uzeti u obzir i stratifikaciju koja je nastala učestalošću dodira sa sjedilačkim civilizacijama. Tada se naime iz prilično egalitarnog društva uzdiže sloj klanskih i plemenskih prvaka koji se ženidbenim vezama vezuju uz susjedna sjedilačka društva - primjerice ruskih kneževina, Gruzije ili Horezmije. Oni su često, pod pritiskom ugovora ili nove svojte, prihvaćali njihovu religiju, tako da treba uzeti u obzir i te osobne i političke elemente (Golden, 1998: 181-182; Spinei, 2006: 352). U kasnijem razdoblju, kad su kumanska plemena uklopljena u druge državne zajednice, postojale su značajnije razlike među elitom, koja je mahom prešla na islam, i običnih nomadskih stočara, koji su zadržali svoja stara vjerovanja.

U tim vjerovanjima napose je važan kult vuka. Indoeuropska ratnička društva sjevera i istoka od davnina su povezana sa štovanjem glavnih pre-

15 Ipatijevska kronika, sastavljena od Početne, Kijevske te Kronike Galicije i Volinje, najvažniji je izvor za srednjovjekovnu povijest Rusije. Više o ruskim nazivima, odnosno savezništvima i neprijateljstvima u: Pritsak, 1967; Pritsak, 1982; Golden, 1979/1980.

16 Na ovome mjestu valja spomenuti i koncentrat što ga je o vjerovanjima euroazijskih nomada iznio Jean Paul Roux, a prenosi Golden (1998: 181): „Les divinités impériales ne sont pas celles du peuple et de tribus; le souverain tend au monothéisme, ses sujets au polythéisme; les clans indépendants sont totémistes ou paratotemistes quand, unis, ils sont obligé de reconnaître comme grand ancêtre, ou héros, ce qui était primitivement le seul totem du clan impérial; les uns s'appuient sur le chamanisme que l'autre cherche à éliminir ou, du moins, à asservir.« U hrvatskom prijevodu: »Carska božanstva ne pripadaju puku i plemenima; vladar teži monoteizmu, podanici politeizmu; nezavisni su klanovi totemisti, ili paratotemisti kad su, ujedinjeni, dužni štovati nekog velikog pretka ili heroja koji je izvorno jedini totem carskoga klana; jedni se pouzdaju u šamanizam, koji drugi nastoje ukloniti ili barem porobiti.«

17 O šamanizmu Staroga i Novoga svijeta vidi: Eliade, 1974. 
datora, vuka i medvjeda (Golden, 1998: 188). ${ }^{18}$ Većina turkijskih tradicija prenosi da se njihovi vođe $u$ određenim trenucima mogu pretvoriti u vuka, što je sasvim na tragu drevnih vjerovanja. Peter Golden, navevši dva primjera iz 11. stoljeća, to sažima citirajući Robertu Hamayon (Golden, 1997: 88-90): »Osnivač plemena (...) u biti je životinja, ali je po funkciji čovjek, utoliko što je on roditelj predaka klana $(\ldots) \ll \cdot{ }^{19} \mathrm{Na}$ istome mjestu navodi i vjerovanje orhonskih Turaka da su potekli od vučje roditeljice i ljudskoga roditelja. Nastavlja i s drugim legendama iz turkijskoga svijeta, primjerice da je oguski Tuman-kan razumio jezik vukova i drugih životinja. Grčkorimski svijet također je poznavao vučje tradicije sjevera i istoka: prvi ih je zabilježio Herodot, koji je komentirao pretvaranje Neura, jednog od skitskih naroda, u vukove. ${ }^{20}$ Antički geograf Strabon je etimologiju imena Dačana izvodio od frigijske riječi za vuka - daos, dok ju je Rim još dublje imao u samim temeljima vjerovanja, u legendi o vučici koja je othranila Romula i Rema. ${ }^{21}$

Druga Kipčacima važna životinja jest pas (turk. it ili köpek). Među njihovim antroponimima poznati su kinonimi poput Itlar ili Itük, kao i Kutuz (od turk. qutuz - »ludi pas«) (Golden, 1998: 190). Uloga psa spominje se i prilikom polaganja zakletvi, o čemu zorno svjedoče dva izvora iz sredine 13. stoljeća. Prvi je vezan uz sklapanje saveza između Kipčaka i latinskoga cara Konstantinopola Balduina II. protiv Bizantinaca, što prenosi francuski kroničar Jean de Joinville, a drugi uz ceremoniju vjenčanja ugarskoga kralja Stjepana V. (1270. - 1272.) i kumanske princeze Elizabete 1253. (Berend, 2001a: 107; Berend, 2001b: 246). Tom su se prilikom kumanski prvaci nad psom raspolovljenim mačem zakleli da će Ugarsku braniti od Tatara. Kumani su još, kao i Privolški Bugari, prinosili psa kao žrtvu pod kamen temeljac različitih građevina (Golden, 1998: 192). O tome koliko su životinje bile

18 Usporediti s nordijskim berserker, ratnicima u medvjeđem ruhu, te ûlfhêdnar, »onima s vučjom glavom«.

19 U izvorniku (Hamayon, 1994: 83): »Founder of the tribe (...) is animal by essence but human by function, inasmuch as he begets the forefathers of the clans $(\ldots)$ «.

20 Herodot $(\mathrm{IV}, 105)$ piše da baš i ne vjeruje da se Neuri mogu pretvoriti u vukove na nekoliko dana pa povratiti ljudsko obličje, no tvrdi da se njegov izvor kune u tu priču. Tko su bili Herodotovi Neuri, nije jasno. Slavni slavist Pavel Josef Šafařík (Slovanské starožitnosti, sredina 19. stoljeća) u njima je (dakako) vidio Slavene. Prema novijim tezama, mogli bi biti istočni ogranak Kelta - naime i ime keltskih Volčana potječe od naziva za vuka. Rekonstrukcija je svakako prilično zahtjevna, s obzirom na to da su i jednima i drugima, a tako i Germanima i brojnim drugima, u vjerovanjima vukovi imali važno mjesto.

${ }^{21}$ Prema drugom tumačenju, »vučica« koja je spasila blizance bila bi žena pastira Faustula. Literatura je o tome opsežna i ovdje nije mjesto za ulaženje u rasprave. Samo smo pokušali upozoriti na važnost te životinje u rimskoj mitologiji. 
važne Kumanima svjedoči i zapis bizantskoga kroničara Nikete Honijata (12./13. st.) u kojemu kaže da su »narod bezbožan i vrlo religiozan u isto vrijeme: štuju kao boga prvu životinju koju vide« (Dall’Aglio, 2008/2009: 38).

Zakletva zapečaćena krvlju, kao ova netom spomenuta, stari je stepski ritual koji se prati barem od vremena Skita. Pripadnici konfederacije Xiōngnú, koja je dominirala stepom u vrijeme kineske dinastije Han, u te su svrhe upotrebljavali konjsku krv pomiješanu s vinom, a Ujguri pak ljudsku krv (Golden, 1998: 192). Zakletve su se sklapale i nad mačem, koji je u dogovor ulazio plav, a ako bi se dogovor prekršio, izlazio je crven (tj. obliven krvlju prekršitelja). U kasnom je 12. stoljeću zabilježeno da su Kumani davali zakletvu tako da bi iglom pustili krv iz prsta pa bi strane vezane zakletvom progutale te kapljice, postajući tako osobe s istom krvlju. Drugi je način bio da obje strane vezane zakletvom piju iz bakrene posude oblika ljudskog lica: s time je povezan turkijski termin za zaklinjanje, ant ičmek, koji doslovno znači »ispijanje zakletve« (Golden, 1998: 193).

Turkijski su narodi, pa tako i Kumani, katkad u pogrebnim ritualima prinosili i ljudske žrtve. Prvake su na putu u drugi svijet pratili vjerni sluge, a i njihovi konji, ponekad samo dijelovi te životinje - glava i noge. Srednjovjekovni kroničar Jean de Joinville (prema Spinei, 2006: 355-356) opisuje pogreb jednoga kumanskog prvaka uz kojega je živ sahranjen i njegov najhrabriji ratnik, nakon čega su nad grobom podigli humak. ${ }^{22}$ Niketa Honijat u svojoj kronici bizantskoga 12. stoljeća (Pripovijedanje povijesti) bilježi da su u Trakiji Kumani pokapani s konjima, lukovima i sabljama, ali i sa zarobljenicima. Nalazi iz pojedinačnih i skupnih grobova Kumana naseljenih u Ugarskoj iz 14. stoljeća pokazuju kontinuitet tradicionalnih vjerovanja. Pronađeni su hrana, koja se stavljala uz pokojnika da mu posluži na putovanju u drugi svijet, oružje, nakit i odjeća. U tri je groba pronađen konj, što je bila vrlo raširena praksa stepskih Kumana, kao i ostalih turkijskih nomada. U grobove su stavljani i amuleti (poput kristala i konjskih zubi), zrcala i jaja, kao simbol plodnosti, uz žene (Berend, 2001b: 249-251).

Na ovome bi mjestu valjalo nešto reći i o središnjoj figuri kumanske duhovnosti. Šaman je vrlo ugledan član zajednice, koji se poziva samo u važnim prilikama, a rjeđe ili nikako u svakodnevnim, uobičajenim, ritualnim praksama. Riječ je podrijetlom iz tunguskoga Sibira, ${ }^{23}$ no usvojena je kao tehnički termin za osobu koja je nadarena sposobnošću da predviđa budućnost, pomaže liječenju ili uzrokovanju bolesti, potpomaže razne događaje

22 Spinei (2006) dodaje i da arheološki nalazi (još) nisu potvrdili takva ukapanja.

23 U ruski i u europske jezike riječ je ušla preko tunguskoga, no vjerojatno je potekla od kinesko-budističke inačice sanskrtske riječi śramaṇa (»asket, redovnik «). 
pozitivne za zajednicu te otklanja negativne učinke događajâ (Golden, 1998: 206; DeWeese, 1994; Boyle, 1972: 177-178). Psihološku predispoziciju za to imaju od djetinjstva ili kao posljedicu bolesti ili kakva događaja na neurološko stanje osobe. Šamani nisu samo posrednici između ljudi i duhova, oni su istovremeno i ovi prvi i ovi drugi u toj komunikaciji. Duhovi predaka vrlo su važni za dobrobit zajednice, prisutni su i članovi im prinose darove. Štoviše, vjeruje se da se njihovi duhovi vraćaju u zajednicu tako što novorođenče primi dušu nekog od svojih predaka (Golden, 1998: 196). Uz kultove predaka vezani su kameni spomenici koje turkijski narodi nazivaju balbals, a Rusi kammenye babi (»kamene žene«), iako su to i žene i muškarci, koji sjede na platformi, najčešće držeći neku posudu. ${ }^{24}$ Pronađeno je preko tisuću takvih statua, većinom između Dnjepra i Donecka te sjeveroistočno od Azovskoga mora. Tu su tradiciju klesanja antropomorfnih figura turkijski narodi preuzeli od iranskih etničkih grupa koje su ih izrađivale u razdoblju prije Krista (Spinei, 2006: 356-362).

Šamane kod Mongola u 13. stoljeću spominju i Flamanac Rubruck i Perzijanac Džuvajni. Rubruck (1990: 240-245) ih u poglavlju posvećenom posebno njima naziva divini, a spominje i njihovu riječ cham, od turkijskoga quam (vidi i: Boyle, 1972: 179). Jedna je od funkcija šamana, i turkijskih i mongolskih, da obavljaju čišćenje vatrom, proceduru koju je detaljno opisao Ivan de Plano Carpini. Oni su mogli i preokrenuti tijek bitke: u borbi s Jurčenima u sjevernoj Kini Džingisov sin Tolui iskoristio je moći jednog od turkijskih Kangla koji je promijenio vremenske prilike i izvukao mongolsku vojsku iz okruženja (Boyle, 1972: 190).

Sljedeća je važna životinja Kumana, a i cijele stepe, konj, sada ne u svome transportnom ili ekonomskom aspektu. Konj je ponajprije pogrebna životinja i psihopomp - naime vezan je uz vodstvo duša pri njihovu prelasku među svjetovima. Konj je mitološka slika smrti koja šamanu pomaže da dosegne ekstazu (Eliade, 1974). Šamanov smjer nije nužno izlazni, tj. povezan je i s dolaskom duša novorođenčadi na svijet. Iz svega je toga razvidna važnost ovih posebnih članova zajednice - oni su povezani s rođenjem i smrću, predvidivim i nepredvidivim događajima, stvarnim i duhovnim svijetom.

S obzirom na to da su dospjeli na granice europskoga kršćanstva, Kumani su došli u doticaj s misionarima koji su na sjeveru i istoku Europe širili kršćansku riječ. Što se (pokušaja) pokrštavanja Kumana koji su živjeli uz zapadne obale Crnoga mora tiče, već je sv. Dominik 1206. otišao papi Inocentu III. u Rim da bi od njega ishodio dozvolu za odlazak u misiju Kumanima. ${ }^{25}$

24 Vidi pregledni rad o statuama sa širim popisom važnije literature: Пилипчук, 2013c.

25 O dominikanskome djelovanju među Kumanima vidi i: Spinei, 2006: 353. Širenju kršćanstva među Kumanima rad je posvetio i Осипян, 2005. 
Čini se da su u tridesetim godinama 13. stoljeća franjevci postali aktivniji od dominikanske braće u misijama na istok Europe i Bliski istok. U buli izdanoj u lipnju 1239. papa Grgur IX. izrijekom spominje njihove misije Saracenima, poganima, Grcima, Bugarima, Kumanima i drugim »nevjernicima«. Vilim iz Rubrucka zapisao je da je u stepi istočno od Volge sreo Kumana kojega su u Ugarskoj pokrstili franjevci (Rubruck, 1990: 135-136). No prvi poznati mendikant koji je otišao u područje Velike Bugarske i Velike Ugarske, sjeverno od Kaspijskoga jezera, jest dominikanac Julijan, koji je na prvo putovanje krenuo 1234./1235., a na drugo dvije godine poslije. Već je 1228. na prostoru današnje Rumunjske i Moldavije osnovana Kumanska biskupija, o kojoj je napisana opsežna literatura. ${ }^{26} \mathrm{O}$ osnutku biskupije i njezinu prvom biskupu dominikanskom provincijalu Teodoriku svjedočanstvo je ostavio spomenuti kroničar Alberik. Koliko je bila važna i Crkvi i Ugrima, svjedoči to što ju je papa Grgur IX. već u rujnu 1229. izuzeo iz jurisdikcije ostrogonskog biskupa i stavio pod svoju (Berend, 2001b: 214-215).

Osim svojih šamanističkih vjerovanja Kumani su još, ovisno o geografiji i kontaktima, bili pod utjecajem nestorijanskih, budističkih, islamskih, manihejskih i drugih vjerovanja. ${ }^{27}$ Oni na području Istočne Europe gotovo su svi, prije ili poslije, prihvatili kršćanstvo: u Bugarskoj, Ugarskoj, Bizantu i ruskim kneževinama, u ovim potonjima čak i nakon formiranja Zlatne Horde. $^{28}$

\section{KUMANSKI JEZIK - LINGUA FRANCA CRNOMORSKE STEPE}

U crnomorskim trgovačkim kolonijama početkom 13. stoljeća kumanskim jezikom služili su se osim izvornih govornika i krimske armenske te židovske zajednice. Kad su cijeli prostor osvojili Mongoli, taj je turkijski jezik ostao lingua franca, između ostaloga i zbog toga što je elita osvajača već među sobom sadržavala brojne turkijske elemente iz središnje Azije, a i brzo su se ženidbenim vezama povezali s lokalnim stanovništvom. Vladari Mongolskoga Carstva nikad nisu nastojali asimilirati ili integrirati različite kulture koje su se našle unutar njegovih granica - priznavanje mongolske političke vlasti bilo je dovoljno (Vásáry, 2005a: 105). U tom svjetlu valja gledati i činjenicu da se administracija Carstva služila nekolicinom velikih je-

26 Popis najvažnije literature vidi u: Spinei, 2008; vidi i: Spinei 2009: 154.

27 Složeni problem širenja svjetskih religija među srednjovjekovnim nomadskim narodima euroazijske stepe opisan je u: Khazanov, $1994 \mathrm{~b}$.

28 O različitim aspektima kršćanstva kod Kumana vidi i: Finch, 2008. O kristijanizaciji Kumana u Ugarskoj vidi: Berend, 2001; Jerković, 2006. 
zika, uz prijevode na manje lokalne jezike. Tumači i prevoditelji oduvijek su imali važnu ulogu u životu srednjoazijskih nomadskih carstava (Sinor, 1982), a upravo u mongolsko doba cijeli je prevoditeljski aparat doživio najviše varijanti i širine.

Iako je mongolski jezik pisan ujgurskim pismom bio najprestižniji jezik Carstva, perzijski je svakako bio najznačajniji i najrašireniji jezik, napose administracije. Veliki kanovi i perzijski il-kanovi izdavali su povelje na mongolskome, uz prijevode na perzijski, jer je svakako bilo lakše naći tumača toga jezika, ne samo u Carstvu nego i izvan njega - primjerice u Kini, Indiji i Europi (Vásáry, 2005a: 105). U istočnome dijelu Carstva glavni posrednički jezik bio je kineski, dok je među islamskim svijetom na zapadu to bio arapski. Jedan od najznamenitijih jezičnih spomenika toga razdoblja upravo je Rasulidov Heksaglot (znan i kao Kraljev rječnik), sastavljen u Jemenu šezdesetih godina 14 . stoljeća. ${ }^{29}$ To izdanje sadržava arapski, turkijski, mongolski, perzijski, grčki i armenski glosar te rječito govori o važnosti jezikâ u svakodnevnim kontaktima među pripadnicima brojnih kultura.

Najvažniji sačuvani spomenik iz kojega se može proučavati kumanski jezik jest svezak Codex Cumanicus, koji se danas čuva u Knjižnici sv. Marka u Veneciji (Cod. Mar. Lat. DXLIX). ${ }^{30} \mathrm{U}$ tom je svesku objedinjeno nekoliko djela različitih autora, čiji se sadržaj može podijeliti na dva dijela: u prvome se nalaze priručnik kumanskih riječi s trojezičnim glosarima italolatinskoga, perzijskoga i kumanskoga jezika. Drugi je dio heterogena zbirka vjerskih tekstova, lingvističkih podataka i folklornoga materijala s prijevodima na latinski i dijalekt srednjovisokonjemačkoga jezika. Prvi dio, koji se naziva i »Tumačevom knjigom«, nastao je krajem 13. stoljeća u talijanskim crnomorskim trgovačkim kolonijama, dok su drugi dio, nazvan »Misionarskom knjigom «, najvjerojatnije sastavili njemački franjevci sredinom 14. stoljeća. Kumanski jezik Kodeksa, koji pripada turkijskoj skupini jezika, danas mogu razumjeti turkijski narodi koji žive uz Crno more (Turci, Krimski Tatari), Kazaci i Kirgizi te nekolicina drugih turkijskih naroda u središnjoj Aziji. ${ }^{31}$

29 Moderno je izdanje pod nazivom The King's Dictionary: The Rasûlid Hexaglot - Fourteenth Century Vocabularies in Arabic, Persian, Turkic, Greek, Armenian, and Mongol uredio je Peter Golden, koji je uz Thomasa Allsena i autor uvodne studije (vidi: Golden, 2000).

30 Ovaj odlomak načinjen je prema detaljnom opisu Kodeksa u: Golden, 1992. O Kodeksu vidi i: Pelliot, 1920: 126-129; Плетнева, 2010: 132-133; Spinei, 2006: 324-329; Spinei, 2009: 186187. Ovdje je važno uputiti i na vrlo staro izdanje Kodeksa koje je 1880. priredio Kuun.

31 Za usporedbu rječnika kumanskoga jezika i današnjih riječi u raznim turkijskim jezicima dobra je studija Karahana (2013) u kojoj autor donosi imena životinja koje se spominju u Kodeksu, uz njihove današnje nazive u nekoliko modernih turkijskih jezika. 


\section{NAČIN ŽIVOTA EUROAZIJSKIH NOMADA}

O načinu života i svakodnevici nomada euroazijske stepe napisano je mnogo. ${ }^{32}$ Pastoralni je nomadizam takav da svi članovi zajednice, zajedno s brojnim životinjama, migriraju od jednoga sezonskog pašnjaka do drugoga. ${ }^{33}$ Žive najviše od mesa i mlijeka domaćih životinja te ulovljenih divljih životinja, dok zemljoradničke proizvode nabavljaju razmjenom ili otimanjem. Kad su se duže zadržavali na nekome mjestu, živjeli su u šatorima, a dok su bili u pokretu, u natkrivenim kolima (Spinei, 2006: 329). Iako su bili nomadi, osim nepreglednih stepskih prostranstava uz njih se vezuje i nekoliko gradova. Kumanski kanovi kontrolirali su i dvije vrlo važne luke: Saksin na utoku Volge u Kaspijsko jezero te Sudak na južnome Krimu. Sudak je bio toliko važan za trgovinu 13. i 14. stoljeća da ne treba čuditi što je Crno more nazvano Sudačkim prilikom sklapanja mira mamelučkog Egipta i Bizanta 1281., a tako su ga nazivali i još neki autori toga razdoblja (Spinei, 2006: 332).

Što se socijalne strukture tiče, na vrhu su hijerarhijske ljestvice veliki posjednici stoke, koji se mogu natjecati za mjesto kana. Na njezinu su dnu robovi, koje su Kumani običavali imati više negoli njihovi prethodnici u crnomorskoj stepi. Ruske kronike svjedoče da su kumanski vojskovođe u svojim pohodima odvodili u ropstvo koliko god su mogli ratnih zarobljenika. Oni su najčešće bili namijenjeni otkupu ili prodaji, no mnogi su radili za svoje gospodare (Spinei, 2006: 345). Trgovina robljem bila je vrlo raširena među kumanskim klanovima, kao što će kumanski robovi biti najpopularnija i najraširenija roba u Istočnom Mediteranu i na Crnome moru. ${ }^{34}$

Osim što su bili pastiri-ratnici, Kumani su obično bili drvodjelci ili kovači. Iako su kod njih pronađene keramičke posude, one su najčešće ruske provenijencije jer su Kumani najradije izrađivali bakrene posude, koje su bolje podnosile česte selidbe. Luksuzne proizvode, najčešće skupocjene tkanine, drago kamenje i zrcala, nabavljali su od svojih susjeda razmjenom.

Iz perspektive ljudi Središnje Azije boravak na konju i ratnički pohod sasvim su uobičajena pojava. Štoviše, ni u mongolskim ni u turkijskim je-

32 Možda je najbolji uvod u nomadski euroazijski svijet dao Khazanov (1994a). Vidi i: Плетнева, 1982; recentno je nekoliko preglednih radova o načinu života Kumana sastavio Jaroslav Pilipčuk, vidi: Пилипчук, 2013b i druge radove istog autora.

33 Khazanov (1994a: 71) iznosi da se procjene uglavnom slažu da je bilo osamnaest ili devetnaest životinja na svakog čovjeka. Prikladan omjer različitih životinja, onih za prehranu i onih transportnih, pridonosio je boljoj mobilnosti nomada i bio važnim čimbenikom preživljavanja u stepi.

34 O tome je (još neobjavljeni) doktorski rad na Sveučilištu Columbia napisala Hannah Barker, koja je istraživala u egipatskim, đenoveškim i mletačkim arhivima. 
zicima nije postojala posebna riječ za ratnika, ${ }^{35}$ kao ni generički pojmovi rata i mira, vjerojatno zbog toga što je borba (s elementima ili ljudima) bila konstantna, značila je preživljavanje. Osim toga, zbog razjedinjenosti plemena i nedostatka vlastite centralne državne vlasti koja bi ih stavljala u svoju službu kumanske su jedinice sudjelovale kao pomoćne i(li) plaćeničke u brojnim ratovima drugih naroda. U spomenutoj bitki 1091. kumanske snage čine više od polovine bizantske vojske koja je nanijela odlučujući poraz Pečenezima - opet je riječ o najčešće spominjanom broju od četrdeset tisuća ratnika. Mihael VIII. Paleolog unajmio je kumanske trupe da bi 1259. pobijedio Latine kod Pelagonije (današnje Bitole), u uvertiri vraćanja Konstantinopola (1261.), ${ }^{36}$ izgubljenog u IV. križarskom pohodu 1204. (Vásáry, 2005b: 114; Halperin, 2000: 238). Njima se koristio i u nekoliko europskih kampanja između 1263. i 1275. (Vásáry, 2005b: 114). Sljedeći se spomen Kumana u bizantskoj vojsci nalazi 1292. u neslavnome pohodu na Epirsku Despotovinu.

Nomadska konjica bila je vrlo važan čimbenik Ugarskoga Kraljevstva, u političkom i vojničkom smislu, pa tako Kumani najprije sudjeluju u unutrašnjim ratovima (1261. - 1266.) između kralja Bele IV. i njegova sina Stjepana. Nakon smrti kraljeva Bele IV. (1270.) i Stjepana V. (1272.) ugarske političke prilike obilježene su unutrašnjim sukobima velikaša iz obitelji Csák i Héder. Kruna je prešla na glavu desetogodišnjega kralja Ladislava IV. (1272. - 1290.), znanog i kao Kumanac, koji se, između ostaloga, oslanjao i na kumansku vojničku potporu u sukobima s osnaženim velikašima. Kumanske su snage sudjelovale 1278. i u Bitki na Moravskom polju, kojom je počela stoljetna prevlast Habsburgovaca u Srednjoj Europi. U odlučujuću bitku carskih pretendenata, češkoga kralja Otakara II. Přemysla i Rudolfa Habsburškoga, Ladislav je ušao kao saveznik potonjega i njegova je kumanska laka konjica uzrokovala velike probleme manje pokretnim češkim vitezovima. I brojni su drugi postajali kraljevima, ili to nastojali postići, uz pomoć nomadskih saveznika: primjerice Filip Švapski, koji je u borbama za njemačku krunu 1203. svojoj vojsci pribavio kumanske čete (Jackson, 2005: 17).

Uobičajena mongolska vojnička praksa bila je inkorporiranje podložnih nomadskih naroda u vlastitu vojsku te su ih slali na bojišta daleko od njihove domovine. Tako je slavni general Subotaj nakon Bitke kod Kalke (1223.),

35 Prema analizi Anne Dibo, koja se ubraja u vodeće ruske stručnjake za altajske jezike, postojali su izrazi ${ }^{*}$ dagu (»stranac, tuđinac «) $\mathrm{i}$ *dagi- (»zavaditi $\left.\ll\right)$, koji su dali u mong. ${ }^{*}$ dajin (»rat«) i u turk. jagï- (»rat, neprijatelj«). Moguće je da je riječ o iranskim posuđenicama.

36 I opet većinom Kumani čine odred generala Aleksija Stratigopula, koji je 1261. osvojio Konstantinopol za Mihajla Paleologa. Vidi: Failler i Laurent, 1984: 190-191. 
uz Džingis-kanovo dopuštenje, pripojio Kipčake mongolskim Merkitima i Najmanima te oformio novu jedinicu (Halperin, 2000: 239). Perzijski povjesničari Džuvajni i Rašid al-Din spominju pojavu prvih Kipčaka u Karakorumu za vrijeme kanovanja Džingisova sina Ogotaja. Zbog toga je, između ostaloga, proučavanje turkijskih naroda neraskidivo vezano uz povijest Mongolskoga Carstva, unutar čijih su se granica našli u 13. stoljeću i pod čijim su se vrhovništvom odvijale brojne migracije.

\section{KUMANSKI UTJECAJI NA DRŽAVE JUGOISTOČNE EUROPE: UGARSKO-HRVATSKO KRALJEVSTVO,BUGARSKU I SRBIJU}

Kumani su u dodir s Ugrima došli krajem 11. stoljeća. Najprije su, na poziv detroniziranoga ugarskog kralja Solomona, provalili 1085./1086. u Transilvaniju, odakle su ih Ugri odbili, da bi samo nekoliko godina poslije zadali poraz ugarskoj kraljevskoj vojsci kada se ova uplela u međusobne borbe ruskih kneževa. Već početkom 12. stoljeća spominje se grupa Kumana pod vodstvom zapovjednika imenom Tatar koji se stavio u službu ugarskoga kralja Stjepana II. (1116. - 1131.) (Spinei, 2008: 415-416). Ta epizoda, koja kao da je služila kao generalna proba za ono što će se događati pred tatarsku provalu stoljeće poslije, završila je neslavno: domaće stanovništvo, revoltirano ponašanjem Kumana u Ugarskoj, pobilo je i popljačkalo veliki broj njih. Ipak, otad su ugarski kraljevi često uzimali u službu kumanske jedinice kao plaćenike.

U prvom je valu, neposredno prije provale Mongola u Ugarsku, vjerojatno 1239., stigao kan Kuten s 40.000 svojih podanika. ${ }^{37}$ Za razliku od Oguza i Pečenega, koji su se dotad u manjim valovima već naseljavali u Ugarskome Kraljevstvu te najčešće bili postavljani za njegove graničare, Kumani su se naselili u većem broju i s dobro strukturiranom organizacijom (Berend, 2001a: 103-104). Suvremeni izvještaj o njihovu naseljavanju i o problemima koje je ono izazvalo nalazi se u djelu Rogerija iz Apulije. Domaće se stanovništvo učestalo bunilo zbog toga što su im nomadski došljaci silovali djevojke, a njihova nebrojena krda nanosila tešku štetu na pašnjacima i usjevima. Osim toga, kad bi izbio spor među Kumanom i Ugrinom, sudstvo je bilo

Taj broj koji navodi Rogerije (2010: 29) treba uzeti s rezervom iz nekoliko razloga. Nije naime jasno uključuje li on sve članove srednjovjekovne familiae, sa slugama, ili ne. Osim toga srednjovjekovni je topos da istočni barbari dolaze u skupinama od 40.000 (i višekratnicima toga broja). Prema populacijskim proračunima što ih je načinio András PálócziHorváth, Kumana je u Ugarsku ušlo oko sedamdeset ili osamdeset tisuća. Vidi: Berend, 2002: 71-72; Pálóczi-Horváth, 1989: 61. 
na strani ovoga prvog. Tragični je epilog uključivao ubojstvo kana Kutena zbog sumnje da su ga Mongoli poslali kao špijuna te odmazdu njegovih Kumana koji su bježeći iz zemlje pustošili Kraljevstvo (Rogerije, 2010: 26-45, 56-61).

No unatoč svim tim događanjima kralj Bela IV. ipak je, u želji da obnovi opustošene krajeve i zaštiti zemlju, 1246. pozvao Kumane da se vrate, što su oni i učinili. Naseljeni su kao grupa u unutrašnjost zemlje, između Dunava i Tise te oko rijeka Körös i Maros. ${ }^{38}$ Bili su izuzeti iz jurisdikcije ugarskih velikaša i pod izravnom kraljevom zaštitom. Belin je razlog bio taj što nije od kršćanskih vladara mogao dobiti nikakvu potporu, štoviše, austrijski mu je vojvoda nakon poraza ugarske vojske oteo tri županije i opljačkao izbjeglice. Prema kraljevu priznanju, jedino mu je još bilo preostalo da "pogani brane zemlju od nevjernikâ«. Tu iznimno važnu vezu s novonaseljenim nomadima ojačao je brakom svoga prvorođenog sina Stjepana (V.) kumanskom princezom Elizabetom 1253.

U sljedećih nekoliko desetljeća kumansko je pitanje bilo vrlo važno u Ugarskom Kraljevstvu. Elizabetin sin, kralj Ladislav, zvan i Kumanac (1272. - 1290.), nekoliko je puta mijenjao politiku prema Kumanima, koji su igrali važnu ulogu u ravnoteži moći između kralja i ojačalih velikaša. Najprije je bio na strani »svojih « Kumana kada je pokušao spriječiti provođenje tzv. Kumanskog zakona iz 1279., prema kojem su svi Kumani trebali prihvatiti kršćansko učenje i prestati s nomadskim načinom života. Tri godine poslije stao je na stranu velikašâ u bitki protiv Kumana kod jezera Hód, da bi 1284. potpuno otkazao poslušnost biskupima i provodio vrijeme s Kumanima, ne pojavljujući se ni na sjednicama Kraljevstva. Negativno mnijenje o kralju bilo je toliko da se smatralo da je upravo on pozvao Mongole koji su opet provalili u Ugarsko Kraljevstvo 1285., a ostrogonski ga je biskup Lodomer 1287. i ekskomunicirao. Tako su Kraljevstvo razdirale unutrašnje borbe, dok 1290. kralj nije ubijen, i to kumanskom rukom. Tek se sredinom 14. stoljeća počinju javljati očitiji znakovi integracije Kumana u ugarsko društvo, kad pretežu kršćanska imena nad turkijskima, no taj će proces još trajati i kroz cijelo 15. stoljeće. ${ }^{39}$

Što se Kumana u Hrvatskoj tiče, poznato je da su poharali Slavoniju 1240., nakon što su im Ugri ubili kralja Kutena. ${ }^{40}$ Ono što bi još trebalo istražiti, između ostaloga, jest pojavljivanje pojedinačnih slučajeva, poput spomena

\footnotetext{
8 Vidi kartu 2 kod: Berend, 2002: 59, te kartu kod: Pálóczi-Horváth, 1989: 57.

39 Više o kumanskoj integraciji vidi u: Berend, 2001, također Pálóczi-Horváth, 1975.

40 O tome je esejistički pisao Stanko Andrić (2001).
} 
osobnoga imena Kuman u dalmatinskim dokumentima 13. i 14. stoljeća. ${ }^{41}$ Iako se Kumani nisu naseljavali u hrvatskim krajevima, pojavljivali su se ondje dolazeći (najčešće) iz Ugarske.

Bugarsko-kumanski odnosi mogu se podijeliti u tri razdoblja, od kojih bi prvi bio od druge polovine 11. stoljeća do 1186., drugi do mongolske provale 1241., a treći do kraja 13. stoljeća, kada je cijelo područje pod utjecajem Zlatne Horde (Павлов, 1992: 10). ${ }^{42}$ U prvome razdoblju Kumani su na prostor današnje Bugarske naseljavani kao nomadsko stanovništvo koje je povremeno bilo u službi Bizantskoga Carstva. Godine 1186. u pobuni Asenida ${ }^{43}$ nastaje Drugo Bugarsko Carstvo, nakon čega Bizant više nikad neće biti na Dunavu, svojoj stoljetnoj sjevernoj granici. Kulminacija je to osnaživanja periferije, u području u kojem je ojačala lokalna multietnička aristokracija, u kojoj je, osim Kumana, bilo slavensko-bugarskih, vlaških i drugih turkijskih elemenata. To relativno heterogeno društvo svjesno je odabralo bugarsko ime zbog tradicije, ali i zbog toga što je imalo snažan antibizantski odjek (Nikolov, 2005: 228). Čak i nakon uspješne pobune i stvaranja vlastitoga carstva Bugari su ostali u dosta dobrim vezama s Kumanima sjeverno i istočno od Dunava. Ti su Kumani, kao plaćenici u vojsci, bili uključeni u većinu uspješnih vojničkih kampanji Drugoga Carstva. Ta je bugarsko-kumanska vojska bila zaista znalački organizirana kombinirajući pješaštvo i laku konjicu. Bugarski su zapovjednici iskoristili bizantska taktička znanja $\mathrm{i}$ iskustvo u nomadskom načinu ratovanja, tvoreći tako vrlo organiziranu i uspješnu vojsku (Dall' Aglio, 2008/2009: 41).

O podrijetlu braće Teodora i Asena napisane su brojne rasprave (vidi: Vásáry, 1994; Dall’ Aglio, 2008/2009: 32-33). Čak i ako nisu bili kumanskoga podrijetla (a, po svoj prilici, jesu), imali su s njima dobre kontakte, i zbog prirode svoga posla - trgovali su naime konjima. Dall' Aglio to pitanje razlaže smatrajući da je njihov »osobni« identitet bio vlaški ili kumanski, ali da je njihov »politički « identitet svakako bio bugarski. ${ }^{44}$ Nakon njihove nasilne smrti bugarskim carem 1197. postaje njihov mlađi brat Kalojan, najvjerojatnije oženjen kumanskom princezom, poznat po svojim vojničkim uspjesima

${ }^{41}$ Poput splitskog notara Kumana iz prve polovine 13. stoljeća, koji se spominje u nekoliko dokumenata između 1232. i 1243., splitskog svećenika Kumana (1308.) ili, recimo, dubrovačkog trgovca Dobrohvala Kumana, spomenutog između 1278. i 1301. - vidi: Spinei, 2009: 332.

42 Svakako je neizostavna literatura za proučavanje kumansko-bugarskih odnosa ona koju je napisao Valerij Stojanov (Стоянов, 1992, 2005, 2009, 2011).

43 Dinastija koju su osnovala tri brata: Teodor (Petar), Asen i Kalojan. Postoje različite teorije o njihovu podrijetlu: jedna je kumanska, druga bugarska, a treća vlaška.

44 O Kumanima i Drugome Bugarskom Carstvu vidi i: Dall’ Aglio, 2013. 
i protiv Latina i protiv Bizanta. Godine 1205. bugarsko-kumanska vojska nanosi težak poraz latinskoj vojsci kralja Balduina, koji je tom prilikom i zarobljen (Dall'Aglio, 2008/2009: 29).

Ivan Asen II. (1218. - 1241.) pobjeđuje 1230. uz malobrojnu, ali presudnu pomoć kumanskih odreda epirskoga despota Teodora Duku kod Klokotnice, čime značajno proširuje granice i snagu svoje države. U sljedećih će desetak godina Kumani u dva vala dolaziti u Bugarsku. Prvi će put 1237. izbjeglice iz crnomorske stepe prijeći Dunav i harajući proći Bugarskom južnije do Hadrianopola, a drugi će put 1241. bjegunci iz Ugarske preko Srijema ući u Bugarsku. Kako je kan Kuten, koji je ubijen u Ugarskoj, bio iz klana Terter(oba), čini se vjerojatnim da je car Terter I., bugarski car okrunjen u Trnovu 1280., upravo kumanskoga podrijetla (Vásáry, 2005b: 65-66). ${ }^{45}$

Oni koji su 1240. izbjegli iz Ugarskoga Kraljevstva pojavili su se i u Srbiji, iako nisu sačuvani nikakvi precizni podaci o njihovu kretanju. Ono što se zna jest da su kumanske plaćenike u svojoj službi imali srpski kraljevi Dragutin (1276. - 1282.), ugarski zet, i Milutin (1282. - 1321.) (Vásáry, 2005b: 99-100). Plaćenici iz redova Alana, Tatara i Kumana imali su i odlučujuću prevagu u bratskome kraljevskom sukobu među tom dvojicom, koji se odigrao u prvom desetljeću 14. stoljeća (Узелац, 2009). ${ }^{46}$

\section{ODNOSI KUMANA S RUSKIM KNEŽEVINAMA I KAVKASKOM REGIJOM}

S ruskim zemljama ${ }^{47}$ Kumani imaju vrlo isprepletenu povijest: potisnuti od mnogobrojnijih Qaya, sredinom 11. stoljeća došli su do Dnjepra. Godine 1055. došli su sve do Perejaslavlja, niti sto kilometara jugoistočno od Kijeva, da bi knez Vsevolod s njihovim kaganom Bolušem sklopio dogovor o nenapadanju (Pritsak, 1982: 338). No već 1061. dogodila se prva bitka Rusa i Kumana, u kojoj je prvu pobjedu odnio kagan Sokal, što je označilo početak brojnih ratova, koji su prestali tek mongolskim osvajanjem regije. Kumanska se pozicija učvrstila nakon što su 1068. pobijedili kijevskoga kneza Izjaslava I. Jaroslaviča, čime su uspostavili kontrolu nad prostorom od Aralskoga jezera sve do donjeg Dunava (Spinei, 2009: 116-117). Godine 1097. Kumani se bore na strani Rusa protiv ugarskoga kralja Kolomana, kojega

45 Postoji i mišljenje da je Kutenov klan bio Durut (Dört/Dürüt) što ga Golden (1995/1996) spominje na str. 112.

46 Uzelac svoj rad o Kumanima u Srbiji završava korisnim pregledom antroponima i toponima kumanskog podrijetla.

47 O ruskim kneževinama u ovom razdoblju vidi: Grekov i Brandt, 1962. Koristan rad o Kumanima, Gruziji i ruskim zemljama jest i: Мургулия і Шушарин, 1998. 
su teško porazili. Svatopluk II. godine 1106. odbija kumansku provalu u Volinju, a godinu poslije dvije ruske kneževske dinastije, i Monomahoviči i Olegoviči, uzimaju za žene Kumanke iz vladajućega klana (Q)ay-opa (Pritsak, 1982: 339). U međuvremenu, u novoj ravnoteži snaga u Podunavlju i na Crnome moru, bizantski car Aleksije 1104. (brakom) sklapa savez s knezom Volodarom od Přemysla, koji je u to vrijeme bio kumanski saveznik. Nato Volodarovi neprijatelji Ugri i Kijev sklapaju svoj savez (Spinei, 2009: 124-125).

Veliki kijevski knez Vladimir II. Monomah (1113. - 1125.) poznat je po tome što je nastojao ujediniti ruske knezove protiv stepskih nomada i po svojim mnogobrojnim kampanjama protiv Kumana. Njegove su pobjede na neko vrijeme obuzdale kumanske provale, vjerojatno čak i presudile tome da Otrok prihvati Davidov poziv da se njegovi Kumani nasele u sjevernoj Gruziji (Spinei, 2009: 127-128). Nakon smrti velikoga kneza Kumani su opet počeli harati - tako su primjerice 1135. provalili u Poljsku. Dakako, nisu ni Rusi ostajali dužni: često su provaljivali u kumansku stepu i otimali konje koji su im trebali za vojne pohode (Noonan, 1992: 311-312). Dvanaesto je stoljeće obilježeno pohodima ruskih knezova i kumanskih hordi, kao i rusko-kumanskih saveza protiv drugih takvih saveza. ${ }^{48}$ Iz toga je razdoblja i ruski nacionalni ep Slovo o vojni Igorevoj (stsl. Слово о пльку Игореви), kоji pjeva vojnu novgorodskoga kneza Igora Svjatoslaviča protiv Kumana na Donu koncem stoljeća. ${ }^{49}$

Dolaskom mongolske vojske u crnomorsku stepu 1221./1222., kumanski kan Kuten poziva upomoć ruske knezove, koji se odazivaju pozivu iako su se dotad više od stoljeća i pol borili baš protiv Kumana. No mongolski je general Subotaj na rijeci Kalki 1223. teško porazio združenu rusko-kumansku vojsku, što je bilo tek uvodom u osvajanje ruske stepe desetljeće i pol poslije, kada je cijeli prostor pripojen Mongolskom Carstvu.

Kumani su se naselili i u Gruziji. Pod zapovjedništvom Arp Arslana (1063. - 1072.) Turci Oguzi, kojima su na čelu bili Seldžuci, napali su Transkavkaziju. Kulminacija sukoba u tom području bila je Bitka kod Manzikerta 1071. Slabljenjem bizantske moći u Anatoliji, otvorio se još veći prostor za oguske provale u Armeniju i Gruziju, koja je patila i od vanjskih i od unutrašnjih problema. No kad je udarom na vlast došao kralj David, nazvan Agmašenebeli (1089. - 1125.), pokrenuo je program obnove i ekspanzi-

48 O granicama ruskih i kumanskih zemalja vidi u: Pritsak, 1982: 340-341. Isti autor u nastavku, na str. 342-368, detaljno navodi dvanaest skupina kumanskih kampova.

49 Pjesmu je preveo Marko Grčić. Postoje dva hrvatska izdanja, oba dvojezična (ruski i hrvatski): Zagreb, GZH, 1988., te Zagreb, Skolska knjiga, 1999. 
je Gruzije. U zamahu velikih uspjeha odlučio je oko 1118. pozvati Kipčake, s kojima je preko žene bio rodbinski povezan. Oni su prihvatili poziv i četrdeset tisuća ratnika došlo je u Gruziju, a mnogi su od njih, prema suvremenom izvještaju, postali i kršćanima (Golden, 1984: 57-58; Ахинжанов, 1995: 143-144). Uskoro je, ojačan kumanskom vojskom koja je brojila petnaest tisuća ratnika, pobijedio Seldžuke u Bitki kod Didgore 1121., čime je uspostavio dominaciju u regiji. ${ }^{50}$

Pozivanje tolikog broja Kumana moglo je biti i pogubno za relativno malu gruzijsku državu. Njihov broj, pod zapovjedništvom Otroka (Atraka), ${ }^{51}$ mogao je dosezati i dvjesto tisuća, no smatram da je, kao i u ugarskom slučaju, taj broj pretjeran. Kralj David dao im je, naravno, plaću za njihove usluge, ali je htio i da ostanu, pa im je dodijelio i dio zemlje gdje su mogli napasati stoku (Golden, 1984: 62). Oni su mu naime bili potrebni da ojača zemlju i da sa svojim »barbarima napada druge barbare«, prema prokušanome kineskom receptu. Dakako, nisu svi Kumani ostali; Otrok se prvi vratio u stepu, no dobar se dio njih naselio u raznim dijelovima zemlje, prema klanovima, jer ih je David htio što prije kristijanizirati i asimilirati (Golden, 1984: 65). Dijelu je kumanskih nomada i odgovarao ostanak u Gruziji, zbog toga što im nakon žestokih borbi s Rusima početkom 12. stoljeća drugo nije ni preostalo jer su izgubili stoku (Golden, 1984: 71). Kada su se 1220./1221. u regiji pojavili Mongoli, dio Kumana bježao je prema Transkavkazju te su zatražili zemlju u Gruziji u zamjenu za svoje usluge. Nakon što su ih Gruzijci odbili, jer su već imali veći broj naseljenih Kumana, došlo je do sukoba. Kumani su poraženi te je dio preživjelih prodan je $\mathrm{u}$ roblje, a drugi se dio raspršio u nepoznatim smjerovima (Golden, 1984: 85).

\section{EGIPATSKI MAMELUČKI SULTANAT}

Kumanske elitne jedinice osnovale su Egipatski Mamelučki Sultanat (1250. - 1517.), koji je 1259. kod Ain Jaluta zaustavio mongolsko napredovanje i 1291. protjerao križare iz Svete Zemlje, čime je uvelike obilježena povijest Bliskog istoka. ${ }^{52}$ Dakako, sami sebe nisu nazivali Mamleucima (od mamlūk - »rob«), ${ }^{53}$ nego najčešće dawla al-turkiyya - »državom Turaka« (Ko-

50 Digdori je četrdeset kilometara od Tbilisija, glavnoga gruzijskoga grada, što ga je David sljedeće godine povratio nakon što su ga osvojili Seldžuci.

51 Pritsak (1982: 338) povezuje Otrokove Kumane s onima što su u 13. i 14. stoljeću bili u Bugarskoj.

52 O ovoj bitki postoji opsežnija literatura. O tome i o odnosima među Mamelucima i Mongolima nakon bitke vidi: Amitai-Preiss, 1995.

53 O instituciji mameluka kao roba u islamskim državama vidi: Jackson, 1990: 340, i ondje navedenu literaturu; napose vidjeti zbirku Ayalon, 1979, i ostale studije toga autora. 
robeinikov, 2008: 379). Sultani i emiri iz prethodne egipatske dinastije Ajubida imali su uza se privatnu konjicu sastavljenu od kumanskih ratnika. Jedan je takav kontingent konjice, četiri tjedna nakon što su zarobili francuskoga kralja Luja IX., izvršio udar i sultanom je postao njihov zapovjednik Baybars. Amitai-Preiss smatra da sultan Baybars ne bi izdržao pritisak Ilkanata da nije bilo trajnog dolaska kumanskih robova u Egipat, koji su uglavnom dolazili iz područja Zlatne Horde. Pokušaji Ilkanata da zabrani tu trgovinu nisu bili uspješni (Amitai-Preiss, 1995: 78-91, 207-211). Naime kan Zlatne Horde Berke, musliman kao i Baybars, dozvoljavao mu je kupnju robova. Tako je kipčački jezik postao govorni i pisani jezik mamelučke vojno-političke elite, koja je, bez obzira na podrijetlo, uzimala i djeci davala turkijska imena da bi se razlikovala od svojih arapskih podanika. Kada je mamelučki sultan htio pohvaliti svoje turkijske pomoćne čete, nazivao bi ih »čistim Kipčacima" (Halperin, 2000: 232). Mamelučke jedinice zadržale su se u egipatskoj vojsci sve do 19. stoljeća, kada su i ovjekovječeni na slikama, poput onih Goyinih, s temom Drugoga svibnja 1808., kada su Napoleonovi carski mameluci nasrnuli na madridski puk koji je protestirao protiv francuske okupacije.

\section{KUMANI NA INDIJSKOME POTKONTINENTU I U KINI}

Delhijski Sultanat, muslimansku državu na sjeveru Indijskoga potkontinenta, osnovao je jedan od kumanskih robova koji su se uzdigli do časti visokih službenika, Qutb-ud-din Aibak, 1206. Premda je i taj sultanat mamelučki kao i (gotovo suvremeni) egipatski, brojne su razlike među njima, ali ipak su vrlo zahvalan komparativni materijal (Jackson, 1990: 341). ${ }^{54}$

Mongoli su mnogo puta provaljivali u sjevernu Indiju tijekom 13. i 14. stoljeća, o čemu postoji opsežna literatura vezana uz vojničke, multietničke i trgovačke aspekte odnosa na granici tih dviju kultura. ${ }^{55}$ Kumani su se u Indiji pojavljivali u robovskoj/vojničkoj službi. Iako su perzijski literati u kronikama Delhijskoga Sultanata znali vrlo precizno razlikovati turkijska plemena i bili upoznati s geopolitičkom situacijom u sjevernim zemljama, $\mathrm{u}$ Indiji se generički termin »Turk « vezivao uz vojne zapovjednike ili robovevojnike (Kumar, 2009: 56).

54 Jackson (2009) zbirka je u kojoj su sakupljene studije o Mongolskome Carstvu i muslimanskoj Indiji u tome razdoblju. To je svakako jedna od važnijih publikacija za proučavanje teme.

55 O mongolskim napadima na Indiju piše već sredinom 13. stoljeća Ivan iz Plano Carpinija. Peter Jackson, jedan od najvećih poznavatelja povijesti Mongolskoga Carstva, napisao je doktorsku disertaciju The Mongols in India, Cambridge University, Department of History, 1976. Recentan pregledni rad o Kipčacima u Indiji jest Пилипчук, $2013 a$. 
Premda je dobar dio ruske historiografije bio sklon vjerovati da je kumanska aristokracija uglavnom uništena u mongolskoj stepskoj kampanji, ipak ima i onih koji pokazuju da je dio tog cvijeta aristokracije odveden u Mongoliju i Kinu (Пилипчук, 2014: 218). Različiti turkijski vojskovođe sudjelovali su u mongolskome osvajanju Kine. Godine 1286. Kublaj-kan osnovao je kipčačku gardu, u koju su ulazili i Kangli i Karluci, a do 1322. dosegnula je broj od trideset pet tisuća vojnika (Пилипчук, 2014: 220). Na čelu joj je bio vojskovođa Tutuha, jedan od prvaka istočnih Kumana, koji je, između ostaloga, bio i nadglednik stada koja su pripadala kanu. On je imao pravo u gardu uvrštavati i Kipčake koji su bili robovi u Kini (Пилипчук, 2014: 226). Drugi Kuman, Esudar, sudjelovao je u osvajanju gradova Xianyanga i Fanchena. Nakon što je promoviran, zapovijedao je stotinama brodova od Žute rijeke do Jangcea, a brodovi kojima je bio na čelu vratili su se iz neuspješne mongolske invazije na Japan bez gubitaka.

\section{UMJESTO ZAKLJUČKA}

Ovaj kratki pregled samo je orisao kostur kumanske povijesti i njihovih utjecaja na razvoj država od Podunavlja na zapadu do Kine na istoku te od ruskih kneževina na sjeveru do Egipta na jugu od 11. do 14. stoljeća. Kumani su se u svoj svojoj etničkoj šarolikosti našli na sponi Europe i Azije u vrijeme kad se sa Zapada polako širila kršćanska Europa te kad je s Istoka mongolska oluja pokorila veći dio azijskoga kontinenta otvorivši ga tako Europljanima nakon stoljećâ zaborava. Već i sami razjedinjeni i bez političke homogenosti, raspršili su se posvuda, najčešće kao plaćeni konjanici koji su donosili prevage u borbama za prijestolja. Jednako velik broj njih bio je odveden ili prodan u roblje koje je služilo na mongolskim, talijanskim i egipatskim dvorovima, no i ovdje s visokom socijalnom mobilnošću. Nekadašnji su robovi u kratko vrijeme postajali najvišim vojnim zapovjednicima, čak i sultanima, što je uvelike utjecalo na razvoj tih država.

Kumanski je način življenja ponajprije bio nomadski, iako je bilo i onih koji su se bavili i poljoprivredom ili živjeli u naseljima, napose ondje gdje su, osiromašeni ili protjerani, na to bili primorani. Dugo su zadržavali svoja šamanistička vjerovanja, čak i kad bi ih sedentizirali i načinili vjernicima većih monoteističkih religija. Zbog takve prirode njihova društva do 15. stoljeća njihovo je ime uglavnom nestalo, osim u brojnim toponimima i etnonimima ${ }^{56} \mathrm{U}$ crnomorskoj stepi, gdje su bili najbrojniji, njihovo je ime zamije-

56 O toponimima u Ugarskoj pisao je László Selmeczi. O toponimima u rumunjskim zemljama vidi: Spinei, 2009: 311-324. Protezali su se i južnije: na sjeveru današnje Makedonije 
njeno tatarskim za vrijeme Zlatne Horde, a u istočnoj su se Europi stopili s već prilično šarenim stanovništvom slavenskoga, ugrofinskoga i turkijskoga podrijetla. U Aziji su dali svoj prilog stvaranju Kazaka, Uzbeka, Kirgiza i drugih turkijskih naroda. Iako sami nisu nikad utemeljili državu, njihovo je nasljeđe u većoj ili manjoj mjeri ugrađeno $u$ desetke europskih i azijskih država i zbog toga je vrijedno proučavanja, napose u okviru euroazijskih dodira koncem srednjega vijeka, u procesu uklapanja nomada u sjedilačke kulture te migracija turkijskih naroda, što je povezano i s izmjenom vjerske slike euroazijskoga kontinenta.

\section{LITERATURA}

Ахинжанов, С. М. (1995). Кыпчаки в истории средневекового Казахстана. Алматы: Гылым.

Amitai-Preiss, R. (1995). Mongols and Mamluks: The Mamluk-Ilkhanid War, 1260-1281. Cambridge: Cambridge University Press, doi: 10.1017/cbo9780511563485.

Andrić, S. (2001). Povijest Slavonije u sedam požara. Zagreb: Durieux.

Ayalon, D. (1979). The Mamluk Military Society: Collected Studies. London: Variorum Reprints.

Berend, N. (2001a). Cuman integration in Hungary, u: A. M. Khazanov i A. Wink (ur.). Nomads in the Sedentary World. Richmond: Curzon Press, 103-127.

Berend, N. (2001b). At the Gate of Christendom: Jews, Muslims and "Pagans" in Medieval Hungary, c. 1000 - c. 1300. Cambridge: Cambridge University Press, doi: 10.1017/ cbo9780511523106.

Boyle, J. A. (1972). Turkish and Mongol shamanism in the Middle Ages, Folklore, 83 (3): 177-193, doi: 10.1080/0015587x.1972.9716468.

Dall'Aglio, F. (2008/2009). The Military Alliance between the Cumans and Bulgaria from the Establishment of the Second Bulgarian Kingdom to the Mongol Invasion, Archivum Eurasiae Medii Aevi, 16: 29-54.

Dall'Aglio, F. (2013). The Interaction between Nomadic and Sedentary Peoples on the Lower Danube: the Cumans and the "Second Bulgarian Empire", u: F. Curta i B. P. Maleon (ur.). The Steppe Lands and the World Beyond Them: Studies in Honor of Victor Spinei on his 70th Birthday. Iaşi: Editura Universității "Alexandru Ioan Cuza", 299-314.

DeWeese, D. (1994). Islamization and Native Religion in the Golden Horde: Baba Tükles and Conversion to Islam in Historical and Epic Tradition. University Park: Penn. State University Press.

Diaconu, P. (1978). Les Coumans au Bas-Danube aux XIe et XIIe siècles. Bucharest: Editura Academiei Republicii Socialiste România.

nalazi se Kumanovo, a na jugu Kumaničevo. No valja obratiti pozornost da ima još daleko više toponima koji nisu vezani uz kumansko ime, nego uz njihov jezik - iako nije lako razlučiti što iz turkijskih jezika dolazi od Kumana, a što od primjerice Pečenega ili Tatara. 
Добродомов, И. Г. (1978). О половецких этнонимах в древнерусской литературе, Тюркологический сборник - 1975, Москва, 102-129.

Eliade, M. (1974). Shamanism: Archaic Techniques of Ecstasy. Princeton: Princeton University Press.

Failler, A. i Laurent, V. (ur.) (1984). Georges Pachymeres. Relations Historiques I-ii: Livres I-iii. Pariz: Peeters Pub.

Finch, R. (2008). Christianity among the Cumans, Surugadai University Studies, (35): 7596.

Golden, P. B. (1979/1980). The Polovcii Dikii, Harvard Ukranian Studies, 3-4 (1): 296-309.

Golden, P. B. (1984). Cumanica I: the Qipčaqs in Georgia, Archivum Eurasiae Medii Aevi, 4, 45-87.

Golden, P. B. (1990). The peoples of the south Russian steppes, u: D. Sinor (ur.). The Cambridge History of Early Inner Asia. Cambridge: Cambridge University Press, 256284, doi: 10.1017/chol9780521243049.011.

Golden, P. B. (1991). The Qipčaqs of medieval Eurasia: an example of stateless adaptation on the steppe, u: G. Seaman i D. Marks (ur.). Rulers from the Steppe. State Formation on the Eurasian Periphery. Los Angeles: Ethnographics Press, Center for Visual Anthropology, University of Southern California, 132-157.

Golden, P. B. (1992). Codex Cumanicus, u: H. B. Paksoy (ur.). Central Asian Monuments. Istanbul: Isis Press, 33-64.

Golden, P. B. (1995/1996). Cumanica IV: the tribes of the Cuman-Qipčaqs, Archivum Eurasiae Medii Aevi, 9: 99-122.

Golden, P. B. (1997). Wolves, dogs and Qipčaq religion, Acta Orientalia Academiae Scientiarum Hungaricae, 50 (1-3): 87-97.

Golden, P. B. (1998). Religion among the Qipčaqs of medieval Eurasia, Central Asiatic Journal, 42 (2): 180-237.

Golden P. B. (ur.) (2000). The King's Dictionary: The Rasûlid Hexaglot - Fourteenth Century Vocabularies in Arabic, Persian, Turkic, Greek, Armenian, and Mongol. Part 8, vol. 4. Leiden - Boston - Köln: Brill.

Golden, P. B. (2005). The Shaping of the Cuman-Qipčaqs and Their World: Origins, Migrations, Political and Cultural Interaction, u: F. Schmieder i P. Schreiner (ur.). Il Codice Cumanico e il suo Mondo. Roma: Edizioni di storia e letteratura, 248-277.

Golden, P. B. (2014). Qipčak, u: N. Demir, B. Karakoç i A. Menz (ur.). Turcology and Linguistics: Éva Ágnes Csató Festschrift. Ankara: Hacettepe Üniversitesi yayinlari, 183-203.

Голубовский, П. В. (1884). Печенеги, Торки и Половцьъ до нашествия Татаръ: История южно-русских степей IX-XIII вв. Київ: Университетская типография И.И. Завадского.

Grekov, B. D. i Brandt, M. (1962). Kijevska Rusija / Ruske zemlje od XII. st. do Ivana Groznog. Zagreb: Naprijed.

Halperin, C. J. (2000). The Kipchak connection: the Ilkhans, the Mamluks and Ayn Jalut, Bulletin of the School of Oriental and African Studies, 63 (2): 229-246, doi: 10.1017/ s0041977x00007205.

Hamayon, R. (1994). Shamanism in Siberia: From Partnership in Supernature to Counterpower in Society, u: N. Thomas i C. Humphrey (ur.). Shamanism, History, and the State. Ann Arbor: Michigan University Press, 76-89. 
Heršak, E. i Lazanin, S. (1999). Veze srednjoazijskih prostora s hrvatskim srednjovjekovljem, Migracijske teme, 15 (1-2): 15-34.

Heršak, E. (2001). Podrijetlo i raseljavanje uralskih naroda, Migracijske i etničke teme, 17 (4): 377-404.

Heršak, E. i Silić, A. (2002). Avari: osvrt na njihovu etnogenezu i povijest, Migracijske i etničke teme, 18 (2-3): 197-224.

Иванов, В. А., Гарустович, Г. Н. і Пилипчук, Я. В. (2014). Средневековые кочевники на границе Eвропь и Азии. Уфа: Башкирский государственный педагогический университет им. М. Акмулды.

Jackson, P. (1990). The Mamlūk institution in early Muslim India, Journal of the Royal Asiatic Society of Great Britain E Ireland (New Series), 122 (2): 340-358, doi: 10.1017/ s0035869x00108585.

Jackson, P. (2005). The Mongols and the West: 1221-1410. Harlow: Pearson, doi: 10.4324/9781315839141.

Jackson, P. (2009). Studies on the Mongol Empire and Early Muslim India. Farnham: Ashgate.

Jerković, M. (2006). Pokrštavanje i kristijanizacija Kumana u Ugarskoj. Prilog proučavanju civilizacijskih dodira u srednjem vijeku, Lucius, 8-9: 173-182.

Kadyrbaev, A. Sh. (2005). Turks (Uighurs, Kipchaks and Kanglis) in the History of the Mongols, Acta Orientalia Academiae Scientiarum Hungaricae, 58 (3): 249-253, doi: 10.1556/aorient.58.2005.3.3.

Karahan, A. (2013). Codex Cumanicus'ta hayvan adlari, Turkish Studies, 8 (1): 1839-1865.

Khazanov, A. M. (1994a). Nomads and the Outside World. Madison: University of Wisconsin Press.

Khazanov, A. M. (1994b). The Spread of World Religions in Medieval Nomadic Societies of the Eurasian Steppes, u: M. Gevers i W. Schlepp (ur.). Nomadic Diplomacy, Destruction and Religion from the Pacific to the Adriatic: Papers Prepared for the Central and Inner Asian Seminar, University of Toronto, 1992-93. Toronto: Joint Centre for Asia Pacific Studies, 11-33.

Кляшторный, С. Г. і Савинов, Д. Г. (2005). Степные империи древней Евразии. СанктПетербург: Филологический факультет.

[Кляшторный, С. Г.] Klyashtornyj, S. G. (2005). The Polovcian problem (II): Qipčaqs, Comans, and Polovcians, Acta Orientalia Academiae Scientiarum Hungaricae, 58 (3): 243-248, doi: 10.1556/aorient.58.2005.5.2.

Korobeinikov, D. (2008). A broken mirror: The Kipçak world in the thirteenth century, u: F. Curta (ur.). The Other Europe in the Middle Ages. Avars, Bulgars, Khazars, and Cumans, Leiden: Brill, 379-412, doi: 10.1163/ej.9789004163898.i-492.95.

Кръстев, А. (2003). Етническијят състав и разселенията на Куманите, Исторически преглед, (5-6): 172-186.

Kumar, S. (2009). The Ignored Elites: Turks, Mongols and a Persian Secretarial Class in Early Delhi Sultanate, Modern Asian Studies, 43 (1): 45-77, doi: 10.1017/ s0026749x07003319.

Kuun, G. (ur.) (1880). Codex Cumanicus. Budapest: Editio Scient., Academiae Hung.

Lăzărescu-Zobian, M. (1984). Cumania as the name of thirteenth-century Moldavia and eastern Walachia. Some aspects of Kipchak-Rumanian relations, u: P. Oberling i G. C. Butash (ur.). Turks, Hungarians and Kipchaks: A Festschrift in Honor of Tibor HalasiKun. Cambridge: Harvard University, Office of the University Publisher, 265-272. 
Мургулия, М. П. і Шушарин В. П. (1998). Половцьы, Грузия, Русь и Венгрия в ХIIXIII веках. Москва: Российская академия наук, Институт славяноведения и балканистики.

Nikolov, A. (2005). Cumani Bellatores in the Second Bulgarian State (1185-1396), Annual of Medieval Studies at CEU, 11: 223-229.

Noonan, T. S. (1992). Rus', Pechenegs, and Polovtsy: Economic interaction along the steppe frontier in the pre-Mongol era, Russian history, 19 (1-4): 301-326, doi: $10.1163 / 187633192 \times 00163$.

Осипян, О. (2005). Поширення Християнства серед Половцив у XI-XIV ст., Київська старовина: науковий історико-філологічний журнал, (1): 3-28.

Pálóczi-Horváth, A. (1975). L'immigration et l'établissement des Comans en Hongrie, Acta Orientalia Academiae Scientiarum Hungaricae, 29 (3): 313-333.

Pálóczi-Horváth, A. (1989). Pechenegs, Cumans, Iasians: Steppe peoples in medieval Hungary. Budapest: Corvina.

Павлов, П. (1992). Средновековна България и Куманите: Военноподитически отношения (1186-1241 г.), Трудове на Великотьрновския университет Св. Св. Кирил и Методий, Исторически Факултет, 27 (3 /1989/): 9-59.

Pelliot, P. (1920). À propos des Comans, Journal Asiatique, 15: 125-185.

Пилипчук, Я. В. (2012). Кыпчаки и Византия (конец XI - начало XIII в.), Исследования по истории Восточной Европы, 5: 41-52.

Пилипчук, Я. В. (2013). Етнополитичний розвиток, Дашт-і Кипчак у IX-XIII cm. Київ: Інститут сходознавства ім. А.Ю. Кримського.

Пилипчук, Я. В. (2013а). Политическая и военная история кыпчаков в Индии в ХІІІ. в., u: Военное дело кочевников Казахстана и сопредельных стран эпохи средневековья и нового времени: сборник научных статей. Астана: BG-print.

Пилипчук, Я. В. (2013b). Ментальность и идеология кыпчаков, Archivum Eurasiae medii aevi, 20: 129-165.

Пилипчук, Я.В.(2013с). “Половецкие бабы” как источник по социальной истории кыпчаков, Казахская Цивилизацุия, 52 (3): 57-68.

Пилипчук, Я. В. (2014). Кыпчаки в Китае, Метаморфозы истории, 5: 217-235.

Плетнева, С. А. (1982). Кочевники средневековья: поиски исторических закономерностей. Москва: Наука.

Плетнева, С. А. (2010). Половцьъ. Москва: Ломоносовъ.

Pritsak, O. (1967). Non-wild Polovtsians, u: To Honor Roman Jakobson. Vol. 2. Den Haag - Paris: Mouton, 1615-1623.

Pritsak, O. (1982). The Polovtsians and Rus', Archivum Eurasiae medii aevi, 2: 321-380.

Расовский, Д. А. (1935-1940). Половцы, Seminarium Kondakovianum, sv. VII: 245-263; sv. VIII: 161-182; sv. IX: 71-75; sv. X: 155-178; sv. XI: 95-128.

Rogerije iz Apulije (2010). Carmen miserabile. Zagreb: Matica hrvatska.

Rubruck, W. (1990). The Mission of Friar William of Rubruck: His Journey to the Court of the Great Khan Möngke 1253-1255. London: The Hakluyt Society.

Sinor, D. (1982). Interpreters in Medieval Inner Asia, Asian and African Studies, 16 (3): 293-320.

Slovo o vojni Igorevoj (1988). Zagreb: Grafički zavod Hrvatske. 
Spinei, V. (2006). The Great Migrations in the East and South East of Europe from the Ninth to the Thirteenth Century. Vol. 2. Amsterdam: Hakkert.

Spinei, V. (2008). The Cuman bishopric - genesis and evolution, u: F. Curta (ur.). The Other Europe in the Middle Ages: Avars, Bulgars, Khazars, and Cumans. Leiden: Brill, 413-456, doi: 10.1163/ej.9789004163898.i-492.97.

Spinei, V. (2009). The Romanians and the Turkic Nomads North of the Danube Delta from the Tenth to the Mid-Thirteenth Century. Leiden - Boston: Brill, doi: 10.1163/ ej.9789004175365.i-482.

Stephenson, P. (2006). Byzantium's Balkan Frontier: a Political Study of the Northern Balkans, 900-1204. Cambridge: Cambridge University Press, doi: 10.1017/cbo9780511496615.

Стоянов, В. (1992). За куманите в източна Европа, Исторически преглед, 1-2: 182-190.

Стоянов, В. (2005). Куманите в българската история (XI-XIV в.), Исторически преглед, 5-6: 3-25.

Стоянов, В. (2009). Куманология: Историографски ескизи. Том 1 и том 2. София: Институт по история при БАН.

Стоянов, В. (2011). За куманския етноним и неговата интерпретация, u: Valeristica Polyhistorica. 1. София: Институт за изторически изследвания рпи БАН, 287-309.

Узелац, А. (2009). Кумани у средњовековној Србији, Гласник, Историјски архив Ваљево, 43: 5-17.

Vásáry, I. (1994). Origins and possible Cuman affiliations of the Asen dynasty, Archivum Ottomanicum, 3: 335-345.

Vásáry, I. (2004). Cuman warriors in the fight of Byzantium with the Latins, Acta Orientalia Academiae Scientiarum Hungaricae, 57 (3): 263-270, doi: 10.1556/aorient.57.2004.3.2.

Vásáry, I. (2005a). Oriental languages of the Codex Cumanicus: Persian and Cuman as linguae francae in the Black Sea region (13th-14th centuries), u: F. Schmieder i P. Schreiner (ur.). Il codice cumanico e il suo mondo. Roma: Edizioni di storia e letteratura, 105-124.

Vásáry, I. (2005b). Cumans and Tatars. Oriental Military in the Pre-Ottoman Balkans, 1185-1365. Cambridge: Cambridge University Press, doi:10.1017/CBO9780511496622. 


\section{The Cuman-Qipčaqs between Asia and Europe in the Late Middle Ages}

\section{Mirko Sardelić}

\section{SUMMARY}

This article presents a general overview of the history of the Cuman-Qipčaq, a loose confederation of Turkic nomadic tribes. While the group never formed a state of their own, the presence of their horsemen in other armies often proved to be a decisive factor in the numerous medieval factional struggles between Rus' principalities, in the Bulgar-Byzantine wars, in internal Hungarian or Serbian struggles, and other conflicts in the wider region. In their heyday (1050-1240) the Cumans controlled the entire area from the Lake Aral to the lower Danube basin. Gordlevski suggests it is impossible to understand the history of Turkic peoples without the Mongols who in the $13^{\text {th }}$ century incorporated many Turkic peoples of the Eurasian steppe into their vast empire. In the same way, any study of Southeast Europe is incomplete without considering the influence of the Turkic peoples. While the Cumans had a history of taking slaves, they themselves would eventually become the most numerous slaves sold in the Black Sea region to Italy, to the Near and the Middle East. However, the Cuman language remained a long-standing lingua franca of the Black Sea steppe and is understood by the majority of Turkic peoples even today. In (South)East Europe the Cumans slowly melted into a colourful ethnic pot of populations of Slavic, Hungarian and Turkic origin. In Asia they contributed to the formation of the Kazakhs, Uzbeks, Kyrgyz and other Turkic peoples. The legacy of the Cumans is woven into dozens of European and Asian nations, and therefore the study of Cuman history is important as a platform for understanding the broader framework of Eurasian migration as well as the relations between nomadic and sedentary societies in that area.

KEY WORDS: Cuman-Qipčaqs, Eurasian steppe, Turkic peoples, Eurasian nomads, Middle Ages, Southeast Europe 